\title{
ETHANOL EXPERIENCES, A REFLECTION ON BRAZILIAN BIOFUELS PRODUCTION
}

\author{
C. DIEPERINK \& S. MAAS \\ Copernicus Institute of Sustainable Development and Innovation, \\ Utrecht University, the Netherlands.
}

\begin{abstract}
Starting in 1975, the Brazilian ethanol programme is the world's oldest and most advanced biofuels programme. Nowadays, ethanol accounts for $40 \%$ of total fuel consumption in Brazil and the country is market leader, responsible for $45 \%$ of the world's ethanol fuel production. The Brazilian ethanol programme can be a source of inspiration for other countries willing to introduce ethanol production. Ideally these countries should try to sustain the positive while reducing the negative sustainability effects of ethanol production. This article discusses the social, environmental, and economic impacts of the Brazilian ethanol programme.
\end{abstract}

Keywords: biofuels, Brazil, ethanol.

\section{THE ROLE OF BIOFUELS IN MEETING ENERGY DEMANDS}

A sustainable future asks for an increasing share of renewable energy sources. Renewables have less environmental effects and make countries less dependent on oil. The latter is especially important for developing countries as oil price increases have 'devastating effects on many of the world's poor countries' and lead to 'increasing risk for many developing economies' [1]. These risks can be reduced if developing countries are willing to start the growth of energy crops. The latter seems to be the case as the market for energy crops is booming. Although the growth of energy crops has contributed to rural development in some places, there is also a growing concern about the negative impacts of the production of biofuels. The downsides become apparent in situations such as in South-East Asia, where the demand for palm oil has resulted in considerable losses of tropical forest. More recently, a tortilla-crisis emerged in Mexico, where the locals could no longer pay the higher prices of maize flower for their tortillas due to the growing demand for maize as biofuel [1]. Brazil provides a different picture in today's newspapers. The country has been using ethanol from sugarcane as a fuel since the late 1920s. After the oil-crisis dictator Ernesto Geisel decided - in 1975 - to create incentives for a home-grown fuel market based on ethanol derived from sugarcane. This Programa Nacional do Álcool (National Alcohol Programme) aimed at the replacement of all automobile fuels from fossil sources (such as gasoline) by ethanol [2].

In this article, we reflect on the Brazilian ethanol programme. The aim of the article is to make an inventory of the sustainability effects of growing and using biomass, and of measures to be taken for a more sustainable production and use. This can be of interest for other countries in the Caribbean, Africa, and Asia that have the potential to seek to replicate the Brazilian ethanol programme [3]. The inventory is based on a review of scientific articles and policy documents. Relevant material was found by using the search term Brazil and ethanol in the search engines Scopus and Google Scholar. Additional information was collected during an expert meeting on Brazilian ethanol organised by the Dutch NGO ICCO (Interchurch Organisation for Development Co-operation) and during discussions with Brazilian stakeholders in Brasilia and Mato Grosso. Following the idea of sustainability balances [4], we categorised the reported and observed impacts of ethanol production into social, environmental, and economic benefits and drawbacks. The benefits and drawbacks found were put on a topic list and discussed in semi-structured interviews with three experts from ICCO, the Brazilian NGO Rede Social, and from the Department of Science, Technology and Society of Utrecht University. The interviewees validated and further specified our initial findings. 


\section{THE BRAZILIAN ETHANOL PROGRAMME}

Brazil is one of the world's largest exporters of agricultural commodities and the major sugarcane producer in the world. It is responsible for $45 \%$ of the world's fuel alcohol production. Table 1 gives an overview of Brazilian land use and ethanol production. Sugarcane is especially grown in the subtropical areas of the Centre and the South, and the tropical areas along the Atlantic in the North-East (see Fig. 1). In the southern state of São Paulo $89 \%$ of the total annual Brazilian yield is produced [5].

Table 1: Brazilian ethanol production in brief statistics $[3,6]$.

\begin{tabular}{lc}
\hline & $2006 / 2007$ \\
\hline Total Brazilian land area (million acres*) & 2103 \\
Area used for agriculture (million acres) & 652 \\
Area used for sugarcane production (million acres) & 15.9 \\
Area used for ethanol production (million acres) & 7.6 \\
Total sugarcane production (million tons) & 426 \\
Total sugarcane produced for ethanol (million tons) & 204.48 \\
Yields (tons/acre) & 31.5 \\
Ethanol production (million gallons**) & 4600 \\
Ethanol productivity (gallons/acre) & 727 \\
Ethanol exports (million gallons) & 800 \\
Costs of production*** (US\$/gallon) & 0.83 \\
Consumer prices (US\$/gallon) & 2.92 \\
Mills in operation & 335 \\
\hline
\end{tabular}

$* 1$ acre $\approx 4046.86 \mathrm{~m}^{2} ; * * 1$ gallon (US liquid) $\approx 3.78$ liter; $* * *$ Data for 2004 .

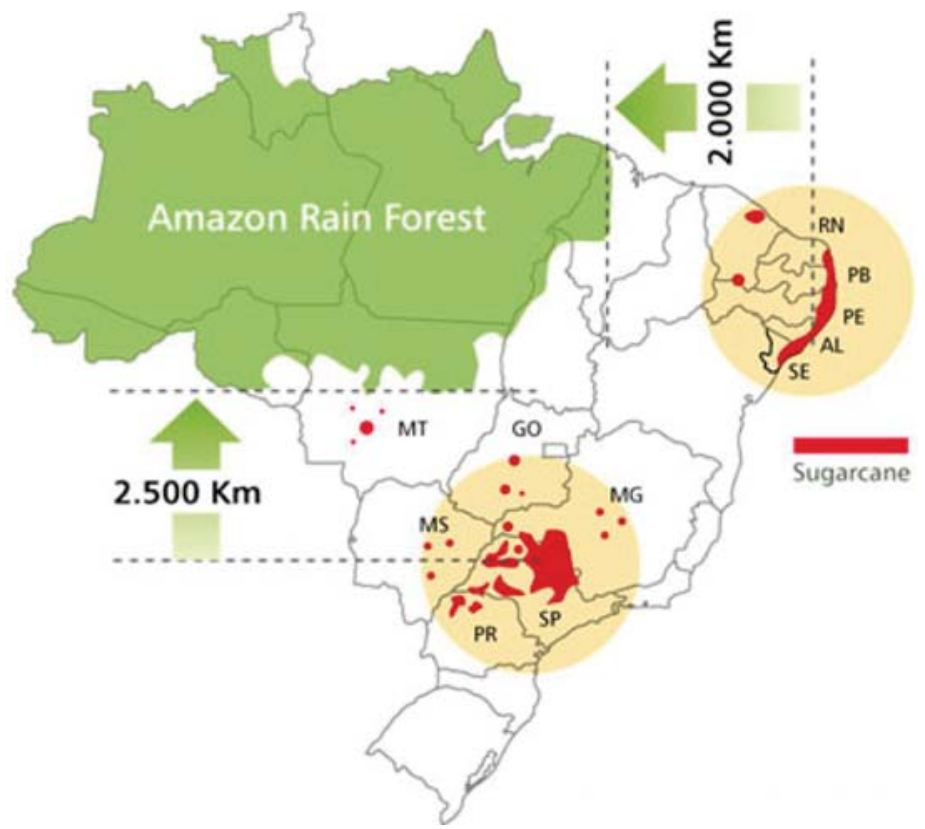

Figure 1: Sugarcane growing areas in Brazil [9]. 
The introduction of the production of sugarcane in Brazil dates back to the beginning of the colonial period. In the middle of the 16th century, Brazil became the world's major producer of sugarcane by supplying Europe with this commodity [5]. Exports to Europe suffered greatly from the 1929 Great Depression leaving the Brazilian sugar industry in chaos. The committee charged with the restructuring of the sugar industry suggested the production of alcohol from sugarcane as a substitute for petroleum and as a way out of the crisis. Although a Sugar and Alcohol Institute, the Instituto do Açúcar e do Álcool (IAA) was set up, cheap oil prices prevented a serious growth of the ethanol industry. During the early 1970s, imported oil accounted for 75\% of Brazil's fuel use [7]. This changed after the 1973 oil crisis. Aim of the 1975 National Alcohol Programme was to reduce the country's oil dependency by creating incentives for ethanol production. The programme was based on two measures [8]. First, 10\% anhydrous ethanol had to be added to gasoline. This measure was not only compulsory but also easily implementable for it did not require changes in the motors as they could run on this 'gasohol'. The second measure, the use of $100 \%$ hydrous ethanol (95\% ethanol $+5 \%$ water) was based on voluntary co-operation of car owners, as it required a modification of motor systems. As all car companies agreed to produce automobiles with converted motors, tanks and pumps for ethanol replaced the ones with gasoline [8].

The Brazilian government subsidised the programme, particularly through 'soft' loans to the sugarcane growers willing to build ethanol distilleries, and incentives to encourage people to purchase pure ethanol-driven cars [8]. Furthermore, the Brazilian government guaranteed low, competitive purchase ethanol prices [3]. As a result by the mid-1980s, nearly all cars in Brazil ran on ethanol [2]. However, a lack of financial supply and rising sugar prices frustrated further expansion and renovations of the sugarcane plantations and factories. Producers began to focus on the export of sugar as raw material again. This led to the 'alcohol shock' in 1989. Long queues of cars had to wait at the gas stations throughout the country and imports of ethanol became necessary [5]. Sales of hydrous ethanol fuelled cars declined rapidly [3] and a growing public concern about fuel shortages led people to resort to gasoline and gasohol again. The situation stabilised over time as government-regulated ethanol prices ensured producers of economic gains and consumers of sustained supplies. Higher world market prices for gasoline made ethanol more competitive. The Brazilian government therefore decided in May 1997 to liberalise the price of anhydrous ethanol, to be followed in February 1999 by a liberalisation of the price of hydrous ethanol $[10,11]$. The introduction of flex-fuel cars in 2003 stimulated a further use of ethanol over gasoline. Flex-fuel cars have engines that recognise the type of fuel and automatically adjust the engine combustion, allowing consumers to choose at the pump the type of fuel they want [3]. As a result the threat of another 'alcohol shock' has been sharply reduced, because drivers can always resort to other fuel sources.

At the end of 2010, the Brazilian sugarcane industry finds itself in a new cycle of expansion. Brazilian ethanol production is currently growing at a rate of $10 \%$ per year [12]. Ethanol production is growing with hardly any direct subsidies (apart from some minor tax exemptions), although taxes on gasoline are as high as $44 \%$ (the latter being only a fraction of taxes in Europe) [3]. The government of president Luiz Inácio Lula da Silva planned to expand the production of sugarcane from 7.6 million acres in 2007 to 12 million acres in 2017 [13] and Brazilian entrepreneurs are investing approximately US\$ 14.6 billion. In the period 2007-2013, no less than 77 new plants will be constructed, while some of the 335 existing plants are scheduled for upgrades or expansions [3]. Technology is being developed that enables the use of bagasse (cane waste) and straw of sugarcane plants in the ethanol production process too. It is expected that hydrolysis of these cellulosic materials will result in a future growth of ethanol production [3].

Rising oil prices combined with commitments of the developed countries to mitigate the effects of climate change will have a positive impact on the demand for ethanol and other biofuels [5]. Ideally, these growing demands will be met with a positive sustainability effect. The latter implies that 
Table 2: Benefits and drawbacks of Brazilian ethanol production.

\begin{tabular}{|c|c|c|}
\hline & Benefits & Drawbacks \\
\hline Social impacts & $\begin{array}{l}\text { Development of rural areas } \\
\text { Employment of unskilled } \\
\text { people }\end{array}$ & $\begin{array}{l}\text { Slave and child labour } \\
\text { Poor working conditions } \\
\text { Social inequality } \\
\text { Forced migration (higher food prices) }\end{array}$ \\
\hline Environmental impacts & $\begin{array}{l}\text { Improved soil quality } \\
\text { Reduction of greenhouse } \\
\text { gases from fossil fuels }\end{array}$ & $\begin{array}{l}\text { Soil erosion } \\
\text { Water, soil, and air pollution } \\
\text { Deforestation and greenhouse gas } \\
\text { emissions } \\
\text { Biodiversity losses }\end{array}$ \\
\hline Economic impacts & $\begin{array}{l}\text { Cheaper fuel } \\
\text { Growing export markets } \\
\text { Reduction in oil dependency }\end{array}$ & \\
\hline
\end{tabular}

benefits of ethanol production should outweigh drawbacks. In Table 2, we give a brief overview of the social, environmental, and economic impacts of ethanol production we found in literature. We have classified these impacts in benefits and drawbacks, which we will discuss in detail in the following sections.

\section{SOCIAL IMPACTS OF THE ETHANOL PROGRAMME}

The ethanol programme has enabled rural development and has created about 6 million jobs [14]. Direct employment estimates range from 500,000 to 1 million. Many employees are migrant workers who are mostly employed in manual harvesting. They receive an income which is based on the amount they have harvested. The average cane cutter earns 1.8 times the minimum wage during the harvesting period of 8 months. After reallocating this income over the entire year, it equals 1.2 times the minimum wage. Migrant workers are in a vulnerable position as they are confronted with (illegal) outsourcing of contracting. There is a growing tendency of informal and precarious employment [5]. In the past, slave and child labour has been reported [15]. Certain sugarcane areas were said to have had a child workforce of up to 25\% [5]. During the last decade, inspections on working conditions in the sugarcane sector were intensified and a decline in child labour has been observed. However, migrants remain vulnerable. They have to pay high costs for transportation, housing, and food [16]. Moreover, expanding mechanisation processes increase unemployment risks for the sugarcane workers as a modern sugarcane-harvesting machine can replace up to 80 labourers [16].

Apart from an excessive workload, workers also face hard working conditions [15]. Sugarcane cutting is a difficult, repetitive activity. Workers are exposed to chemical pesticides and excessive heat and sunshine [15]. Work-related diseases and injuries have reduced working ability of an average labourer with 10 years. Even deaths have been reported. It is not only the workers who suffer physically from sugarcane and ethanol production and use. Traditionally, sugarcane fields are burned prior to the manual harvesting of sugarcane. In the city of São Paulo, the burning of sugarcane fields is responsible for $80 \%$ of $\mathrm{PM}_{2,5}$ in the air. This has caused a significant increase in respiratory diseases, especially in children and elderly people [5].

Ethanol production is based on a mono-cropping production model that concentrates production on great stretches of land. The cultivation of monocultures has resulted in inequalities in rural areas 
as Brazil has a high land ownership concentration [5]. A large share of the sugarcane production chain is in hands of a few rich magnates, while on the other side according to the Brazilian government around 3.1 million people are landless [15]. The expansion of sugarcane production in Mato Grosso and Mato Grosso do Sul has postponed the demarcation of indigenous land rights [15]. Small farmers are threatened by expanding sugarcane production, and are often forced off their lands [16]. Furthermore, the positive effects of sugarcane and ethanol production often do not reach the poorest households, and lead to unequal distribution of profits [15]. Apart from this, the rising demand for ethanol competes for land and water with food production. In the state of São Paulo, production of tomatoes, peanuts, and oranges is being substituted by sugar [16]. Some claim that this expansion of sugarcane production has driven up average food prices in Brazil [15, 17]. However, a closer look at Table 1 shows that this is unlikely as only a limited amount of the Brazilian agricultural area $(0.011 \%)$ is used for ethanol production.

\section{ENVIRONMENTAL IMPACTS OF THE ETHANOL PROGRAMME}

During its growth sugarcane has positive effects on soil quality. Its root system offers reposition of organic material to the soil, restructures it, and activates the living part of the environment, improving the conditions for water retention and soil percolation [5]. However, sugarcane production also causes soil erosion because the whole sugarcane biomass is harvested and processed for ethanol production. Removing the biomass leaves the soil unprotected and exposed to erosion from rainfall and wind, especially when sugarcane is grown on slopes [18]. The burning of the fields not only stimulates soil erosion but has negative effects on air and water quality and health as well as it emits acids and other toxic chemical compounds [16]. At the moment, sugarcane burning is being phased out and subsequently the introduction of mechanised harvesting will decrease the negative impacts on air quality and health [19]. Furthermore, soil erosion can be prevented by techniques such as contour ploughing and bench terracing [16]. However, so far Brazilian legislation doesn't addresses erosion prevention.

In the process of growing sugarcane large quantities of pesticides and nitrogen fertiliser are used, which lead to pollution of soils and ground and surface water [18]. Inadequate disposition of vinasse (a by-product of sugarcane production) also results in contaminations [5]. However, compared with conventionally grown Brazilian crops like maize, coffee, and soybeans the use of pesticides and fertilizers in growing sugarcane is considerably limited [16]. Table 3 illustrates this by comparing the inputs required for the production of ethanol and maize [20].

Table 3: Required agrochemical inputs for growing sugarcane ethanol and maize [20].

\begin{tabular}{lcc}
\hline & $\begin{array}{c}\text { Sugarcane } \\
\text { ethanol }\end{array}$ & Maize \\
\hline Nitrates (kg/ha) & 25.0 & 140.0 \\
Phosphates (kg/ha) & 37.0 & 100.0 \\
Kalium (kg/ha) & 60.0 & 110.0 \\
Liming materials (kg/ha) & 600.0 & 500.0 \\
Herbicides (1/ha) & 2.6 & 13.0 \\
Drying hormone (1/ha) & 0.4 & - \\
Insecticides (1/ha) & 0.1 & 2.2 \\
Nematicides (1/ha) & 1.2 & - \\
\hline
\end{tabular}


Most sugarcane growing areas require no irrigation [21], but in the process of fermentation and distillation in the mills, a lot of water is used. Sugarcane is crushed and squeezed and mixed with water, leading to a $10 \%$ ethanol, $90 \%$ water mixture. The production of 11 of ethanol results in about 101 of wastewater that has to be disposed of [18]. Nowadays, most of the liquid nutrient-rich wastes are either recycled within the production process or reused for ferti-irrigation, the process wherein wastes are applied as fertiliser in sugarcane fields [16]. Possible negative ecological effects could occur if the production of genetically modified (GM) cane will grow. However, so far scientific consensus on the environmental effects of GM organisms is lacking [16].

Using ethanol and bagasse instead of gasoline (1 1 of ethanol substitutes 0.81 of gasoline [5]) has reduced Brazil's annual greenhouse gas emissions by 25.8 million tons $\mathrm{CO}_{2}$ equivalent, which is substantial compared with the country's total annual emission of 92 million tons $\mathrm{CO}_{2}$ equivalent [21, 22]. In principle, biofuelled motors emit $\mathrm{CO}_{2}$ that had been taken out of the atmosphere and stored through photosynthesis in the sugarcane plants. However, in the production of ethanol in Brazil fossil fuels are used to power farm machines and trucks. Ethanol from sugarcane has an energy balance of at least 1:8, which means a fossil-fuel input of 1 unit results in an ethanol output of 8 units [2]. The input of fossil-fuel can be reduced as in modern ethanol plants, the heat and electricity necessary for the industrial processes is obtained through the burning of bagasse in co-generation systems, which also produce electricity for the national network. The use of bagasse by the Brazilian mills is equivalent to 11 million tons of fossil fuel. Future efficiency of this co-generation system can be improved by optimising the use of bagasse and by also using sugarcane straw (which today is left in the field or burned before harvest). The use of straw would result in a substitution of 3.2 million tons of fossil fuel [5]. Apart from $\mathrm{CO}_{2}, \mathrm{CH}_{4}$ and $\mathrm{N}_{2} \mathrm{O}$ are emitted during the production and use of ethanol. Methane emissions result from the burning of sugarcane fields, from burning bagasse, and from ethanol combustion in engines. The burning of sugarcane fields and soil management also result in $\mathrm{N}_{2} \mathrm{O}$ emissions [22]. Table 4 gives an overview of the emissions and avoided emissions of ethanol production and use in Brazil.

Sugarcane production expanded in the last three decades in areas up till then used for extensive cattle-raising and agricultural plantations. As sugarcane needs a dry season, it would not be a good crop to move into the Amazon region [21]. However, current growth in the sugarcane sector could provoke the displacement of cattle and soybean production to the agricultural frontier. The direct occupation of new natural areas in the south of the cerrado region (Brazil's tropical savannas, see Fig. 2) and in the North of Brazil could have a negative impact on habitats, biodiversity, and $\mathrm{CO}_{2}$ emissions [15] because of further deforestation and eutrophication resulting from fertiliser use [5].

Table 4: Net avoided greenhouse gas emissions of ethanol use and production in Brazil $\left(\mathrm{kg} \mathrm{CO}_{2}\right.$ eq./ ton of cane) [22].

\begin{tabular}{lll}
\hline Avoided emissions & Extra emissions & Net avoided emissions \\
\hline
\end{tabular}

Fossil fuel substitution $242.5 \quad$ Fossil fuel use 19.2

(A)/169.4 (H)

Surplus from bagasse use 12.5 $\quad \mathrm{CH}_{4}+\mathrm{N}_{2} \mathrm{O}$ from trash burning 9.0

$\mathrm{N}_{2} \mathrm{O}$ from soil 6.3

$\begin{array}{lll}\text { Total } 255.0(\mathrm{~A}) / 181.9(\mathrm{H}) & \text { Total } 34.5 & 220.5(\mathrm{~A}) / 147.4(\mathrm{H})\end{array}$

$(\mathrm{A})=$ anhydrous ethanol; $(\mathrm{H})=$ hydrous ethanol. 


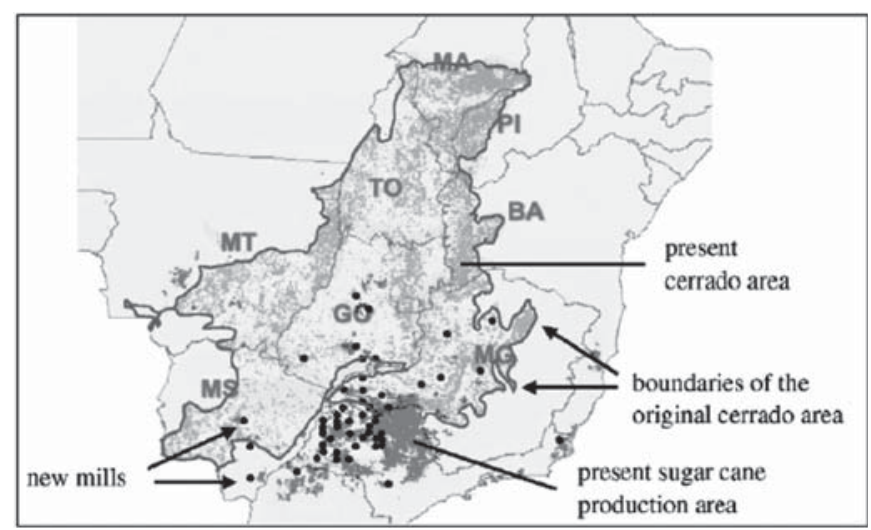

Figure 2: Sugarcane growing areas, the cerrado and new mills in Brazil's central South [16].

\section{ECONOMIC IMPACTS OF THE ETHANOL PROGRAMME}

Government actions, especially the mandatory addition of $20-25 \%$ of ethanol to gasoline have had a positive effect on the production of ethanol. Economies of scale and growing competition have led to a reduction in production costs [8] and resulted in viable production sector. The focus on the growing external market has led companies to enlarge and diversify their products, as well as invest in quality control systems, technology, and research. Investments in the infrastructure in the central parts of the country and in the ports are accompanying this tendency. Recently, companies have been privatised, mergers have taken place, and the influx of capital from abroad has grown $[5,15]$. Ethanol exports from Brazil are growing at up to $50 \%$ per year, and nowadays export accounts for $20 \%$ of total yearly ethanol production [12]. Since the 1990s, governmental subsidies have been progressively reduced although credit facilities for the sugar and ethanol sector still exist [5]. Overall, subsidies for ethanol production are estimated to have been around US\$30 billion over 20 years, but they were more than offset by a US\$ 50 billion reduction of petroleum imports as of the end of 2006 [19]). Consumers benefit from the ethanol programme as they can get fuel for highly competitive prices. The 2007 retail price for a gallon of gasohol was US\$ 4.91 while ethanol with equivalent energy content cost only US\$ 3.88. Plain gasoline was even more expensive [2]. Finally, the Brazilian ethanol programme has led to a significantly reduced dependence of Brazil upon oil-exporting countries. The availability of home-grown fuels has made the country less vulnerable for rising oil prices and geo-political tensions [19].

\section{LESSONS FROM BRAZIL}

As sugarcane grows in (sub) tropical areas with a dry and a wet season, countries like Latin America, the Caribbean, Central Africa, and South-East Asia have the opportunities to invest in the production of ethanol $[7,23]$. If these countries have enough land available, starting ethanol production is a promising strategy towards a more sustainable energy system. They should however be able to keep the balance between positive and negative social, environmental, and economic impacts of ethanol production. Tables 5 and 6 summarise the lessons we have drawn from the Brazilian case after some discussions with our interviewees. The lessons are specified into recommendations that address the people (social), planet (environmental), and profit (economic) dimensions of sustainability.

The Brazilian case shows that the sugarcane industry has provided incentives for rural development, but a more equal land distribution is considered important in ensuring that benefits of the 
Table 5: Recommendations to sustain and improve positive effects of ethanol production.

Make sure that industries contribute to rural development by ensuring that benefits are

¿ spread amongst the population

Create minimal greenhouse gas emissions by spurring technological development and

$\vec{\Xi}$ efficiency, for instance through the co-generation of bagasse and other by-products

$\frac{\Xi}{2}$ Ensure that there is a positive energy balance, and aim at increasing the energy balance ratio by increasing efficiency

Create a price advantage for the ethanol industry, through government interventions such as subsidies and tax breaks or with assistance from developed countries

Co-operate with other relevant industries, such as the automobile industry

Table 6: Recommendations to reduce negative effects of ethanol production.

Create better working conditions, by directly contracting labourers and paying them per hour

Make sure sugarcane workers have access to adequate personal protection and health services

Start policies to make sure that ethanol production does not compete with food production

$\sim$ Establish land property legislation and property rights in order to reduce income inequality and unequal land distribution

Set up and enforce laws in order to protect minority groups such as landless and indigenous people and to prohibit child and slave labour

Regulate land use to protect biodiversity and reduce further pressure on land, limit expansion of sugarcane growing to former agricultural lands

$\rightleftarrows$ Set up and enforce national soil, air, and water quality standards

$\frac{\text { ज }}{\alpha}$ Do not harvest the entire sugarcane biomass and apply soil erosion prevention techniques

Reduce water use and reuse waste water as much as possible, preferably creating a closed water cycle

Create a competitive industry, if necessary by making use of government investments and market protection

Concentrate on fuel substitution on the national market, as exports result in an increased

energy use for transportation

Limit concentration of land ownership and wealth by enforcing property rights and by prohibiting the verticalisation of companies

industry will be spread amongst the population. The Brazilian ethanol programme has also led to major reductions in greenhouse gas emissions, but further reductions require a broader application of innovative techniques for co-generation of bagasse and other by-products. Over time, Brazil managed to achieve a price for ethanol that is lower than that for gasoline. This shows that government regulations, subsidies, and tax breaks are important in creating a competitive industry. Donor countries could also play a role in providing the necessary money, for instance through the Clean Development Mechanism. Co-operation of the Brazilian government with existing industries was of key importance to the success of the ethanol programme. The fact that automobiles with converted 
motors were produced and infrastructure for ethanol pumps was created around the country was essential to the success of the programme.

People working in the sugarcane sector in Brazil experience destructive working conditions, growing unemployment, and a high level of social inequality and exploitation. These conditions could be avoided by direct contracting instead of outsourcing the contracting. Trade unions could support these processes. It is also advisable to pay labourers per hour as production-based payments result in too long working days. Furthermore, sugarcane workers should have access to adequate personal protection and health services. Laws should also be enforced to prohibit child and slave labour. Land property legislation and enforcement are also required to protect the position of indigenous and minority groups. In order to ensure that the production of ethanol from sugarcane does not lead to inadequate food supplies, policies and laws should be created that prescribe that sugarcane should only be grown on land not used for food production. Land use regulations are necessary to ensure that sugarcane plantations do not expand uncontrolled and to ensure that biodiversity losses will be prevented. Sugarcane plantations should only be set up in former agricultural areas and indirect deforestation (by displacements of other crops) should be prevented. By leaving some of the sugarcane standing instead of harvesting all the biomass, soil erosion can be reduced. National standards for water and soil quality should be set up in order to limit the use of pesticides and fertilisers. Wastewaters should be treated as well. Companies can avoid local air pollution by resorting to mechanical harvesting of sugarcane instead of burning the fields. However, such an investment is politically sensible as it will decrease employment opportunities.

\section{CONCLUDING REMARKS}

The Brazilian case shows that ethanol production can be a promising strategy towards a more sustainable energy system. The Brazilian ethanol programme has resulted in a reduction of greenhouse gas emissions, less dependency on oil-exporting countries, and the development of rural areas. On the other hand, several drawbacks of the programme were perceived as well. It is a challenge for countries willing to copy the Brazilian programme to keep the balance between benefits and drawbacks, while creating a competitive industry. The latter asks for responsible businesses as well as pro-active governments, which are on one hand willing to attract investors using fiscal instruments, and on the other hand willing to reduce external effects of ethanol production by setting up and enforcing regulations. The Brazilian ethanol programme has been widely subsidised and supported by the government before ethanol could become a competitive fuel source. Therefore, one should recognise that setting up similar programmes requires significant and long-lasting government investments and a consequent market protection. Such policies are not always easy to implement and require stable governance structures, which are not always present in countries interested in copying the Brazilian example.

\section{ACKNOWLEDGEMENTS}

The authors would like to thank Henk Gilhuis (ICCO), Maria Luisa Mendonça (Rede Social), Martin Junginger (Utrecht University) for sharing their knowledge and two anonymous reviewers for their constructive remarks on an earlier draft of this article.

\section{REFERENCES}

[1] United Nations, Sustainable Bioenergy: A Framework for Decision Makers, Online: http://esa. un.org/un-energy/pdf/susdev.Biofuels.FAO.pdf, 2007.

[2] Bourne, J.K., Green Dreams, Making fuel from crops could be good for the planet - after a breakthrough or two. National Geographic, 212(4), pp. 38-59, 2007.

[3] Budny, D., The Global Dynamics of Biofuels - Potential supply and demand for ethanol and biodiesel in the coming decade, Brazil Institute Special Report: Washington, 2007. 
[4] Koens, J.F., Dieperink, C. \& Miranda, M., Ecotourism as a development strategy, Experiences from Costa Rica, Environment, Development and Sustainability, (11), pp. 1225-1237, 2009. doi:http://dx.doi.org/10.1007/s10668-009-9214-3, http://dx.doi.org/10.1007/s10668005-9000-9

[5] Rodrigues, D. \& Ortiz, L., Dutch import of biomass - Producing countries point of view on the sustainability of biomass exports. Case study: sugar cane ethanol from Brazil, Online: http://www.bothends.org/strategic/061211_Biomass\%20case\%20study\%20Brazil.pdf, 2006.

[6] European Commission, Monitoring Agri-trade Policy. Brazil's Agriculture: a Survey, Online: http://ec.europa.eu/agriculture/publi/map/02_06.pdf, 2006.

[7] Goldemberg, J., The ethanol program in Brazil. Environmental Research Letters, 1(1), Online: http://www.iop.org/EJ/volume/1748-9326/1, 2006.

[8] UNICA, The industry - Production map, Online: http://english.unica.com.br/, 2008.

[9] Rothman, H., Greenshields, R. \& Callé, F.R., The Alcohol Economy: Fuel Ethanol and the Brazilian Experience, Frances Pinter Publishers Ltd: London, 1983.

[10] Goldemberg, J., Coelho, S.T., Nastari, P.M. \& Lucon, O., Ethanol learning curve - the Brazilian experience. Biomass and Bioenergy, 26(3), pp. 301-304, 2003.

[11] Wang, M., Learning from the Brazilian biofuel experience. Environmental Research Letters, 1(1), Online: http://www.iop.org/EJ/toc/1748-9326/1/1

[12] Friends of the Earth, Harvesting Harm: Agrofuels as a False Solution to Climate Change and Poverty. Policy Brief on the Inter-American Development Bank Agrofuels Strategy. Online: http://www.foei.org/en/resources/publications/pdfs/2008/HarvestingHarm.pdf , 2008.

[13] Heijt, H., Doubts about plea Lula bio-ethanol (in Dutch), Nederlands Dagblad, p. 8, 9-4-2008.

[14] Dufey, A., Impacts of sugarcane Bioethanol towards the Millennium Development Goals. Sugarcane ethanol. Contributions to climate change mitigation and the environment, eds P. Zuurbier \& J. van de Vooren, WAP: Wageningen, pp. 199-226, 2008.

[15] Suárez, S.M., Bickel, U., Garbers, F. \& Goldfarb, L., Agrofuels in Brazil: Fact-Finding Mission Report on the Impacts of the Agrofuels Expansion on the Enjoyment of Social Rights of Rural Workers, Indigenous Peoples and Peasants in Brazil, FIAN International: Heidelberg, 2008.

[16] Smeets, E., Junginger, M., Faaij, A., Walter, A., Dolzan, P. \& Turkenburg, W., The sustainability of Brazilian ethanol - An assessment of the possibilities of certified production. Biomass and Bioenergy, 32(8), pp. 781-813, 2008. doi:http://dx.doi.org/10.1016/j.biombioe.2008.01.005

[17] Dros, J.M., Personal Communication, Solidaridad: Utrecht, 2009.

[18] Pimentel, D. \& Patzek, T., Ethanol Production: Energy and Economic Issues Related to U.S. and Brazilian Sugarcane. Natural Resources Research, 16(3), pp. 235-242, 2007. doi:http:// dx.doi.org/10.1007/s11053-007-9049-2

[19] Goldemberg, J., Ethanol for a Sustainable Energy Future. Science, 315(5813), pp. 808-810, 2007. doi:http://dx.doi.org/10.1126/science.1137013

[20] Neves do Amaral, W.A., Marinho, J.P., Tarasantchi, R. \& Beber, A., Giuliani, Environmental sustainability of sugarcane ethanol in Brazil. Sugarcane ethanol. Contributions to climate change mitigation and the environment, eds P. Zuurbier \& J. van de Vooren, Wageningen Academic Publishers: Wageningen, pp. 113-138, 2008.

[21] Marris, E., Drink the best and drive the rest. Nature,444(Dec),pp. 670-672, 2006. doi:http://dx.doi. org/10.1038/444670a, http://dx.doi.org/10.1038/444985a, http://dx.doi.org/10.1038/444684a

[22] Macedo, I.C., Leal, M.R.L.V \& Silva, J.E.A.R., Assessment of greenhouse gas emissions in the production and use of fuel ethanol in Brazil, Online: http://www.riaed.net/IMG/pdf/GHG_ sugarcane_engl.pdf, 2004.

[23] FAO, Data Sets of selected Global AEZ assessment result: Suitability results for sugarcane under rain-fed conditions, Online: http://www.fao.org/ag/AGL/agll/gaez/ds/da.htm?map=24, 2000. 